\title{
The Effect of Job Stress and Job Satisfaction on Employee Performance through Commitment as an Intervening Variable (Case Study on Grabbike Drivers in Palembang City)
}

\author{
Ismail Marzuki, Agustina Hanafi, Yuliani
}

\begin{abstract}
This study aimed to determine the effect of job stress and job satisfaction on performance through organizational commitment as an intervening variable in the study Grabbike driver Palembang. The sampling method was purposive sampling with a total sample of 100 respondents. The analysis technique used in this study is the Structural Equation Model (SEM). The results showed that job stress has a significant and negative direct effect on organizational commitment and performance. Job satisfaction has a significant and positive direct effect on organizational commitment and performance. Organizational commitment has a significant and positive influence on performance. Job stress has a significant effect on performance through organizational commitment. Job satisfaction has a significant effect on performance through organizational commitment.
\end{abstract}

Keywords: Job Stress, Job Satisfaction, Organizational Commitment, Performance

\section{INTRODUCTION}

Stressi ress is a dynamic condition in which a person is faced with demands, opportunities or resources related to what individuals want and which results are seen to be uncertain and important (Robbins \& Judge, 2015: 429). Job stress regularly affects employees in the workplace, which every employee will experience at least once in their workplace. Job stress is also defined as a dangerous physical and emotional response that can occur while doing work (Olaimat, 2017). Work stress will also make Grabbike drivers feel uncomfortable and feel dissatisfied with the work they are doing.

Job satisfaction is a driver of employee results. Job stress will also make Grabbike drivers feel uncomfortable and feel dissatisfied with the work they are doing, or the organization because satisfaction was work is the result of employee

Manuscript received on May 10, 2021.

Revised Manuscript received on May 17, 2021.

Manuscript published on May 30, 2021.

* Correspondence Author

Ismail Marzuki*, Student Magister Management, Economic Faculty of Sriwijaya University, Palembang, Indonesia Email: ismailmarzuki280694@gmail.com

Agustina Hanafi, Lecturer of Magister Management, Economic Faculty, Sriwijaya University, Palembang Indonesia

Yuliani, Lecturer of Magister Management, Economic Faculty, Sriwijaya University, Palembang Indonesia

(c) The Authors. Published by Blue Eyes Intelligence Engineering and Sciences Publication (BEIESP). This is an open access article under the CC BY-NC-ND license (http://creativecommons.org/licenses/by-nc-nd/4.0/) perceptions regarding how well his work provides things that are considered important (Kaswan, 2017). Employees who have high job satisfaction will do their jobs with enthusiasm and motivation. This of course will benefit the company because productivity will indirectly increase. In addition, good job satisfaction will encourage employees to have loyalty and commitment to the company.

According to Triatna (2015: 120) commitment in the organization is a level of employee loyalty to the organization which is characterized by a desire to remain part of the organization, do the best for the organization, and always maintain the good name of the organization. Organizational commitment encourages employees to have a strong bond with the company so that they are willing to do anything to achieve the company's goals. Organizational commitment will encourage employees to do their job optimally so that employee performance can be better.

Performance can be defined as a result of work that has been achieved by a person in carrying out the tasks assigned to him based on skills, experience and seriousness as well as timeliness .(Hasibuan, 2016: 94). As a service provider company, the performance of this company is highly dependent on employee performance, in this case the drivers who serve consumers (Lailiyah \& Wahyuningsih, 2019).

\section{LITERATURE REVIEW}

\section{A. Definition of Job Stress}

Stress is a depressed state, both physically and psychologically (Mangkunegara, 2017: 92-108). Work stress also means a condition of tension that affects a person's emotions, thought processes, and conditions (Hasibuan, 2016: 76).

\section{B. Definition of Job Satisfaction}

According to Lawler (2015: 180), the measure of satisfaction is very much based on the realities faced and accepted as compensation for the effort and energy given. Job satisfaction depends on the suitability or balance between what is expected and reality.

\section{Definition of Organizatonal Commitment}

Organizational commitment is the level at which a worker identifies an organization, its goals and hopes for it to remain become members (Robbins and Judge, 2017: 47).

Published By:

Blue Eyes Intelligence Engineering \& Sciences Publication

(C) Copyright: All rights reserved.

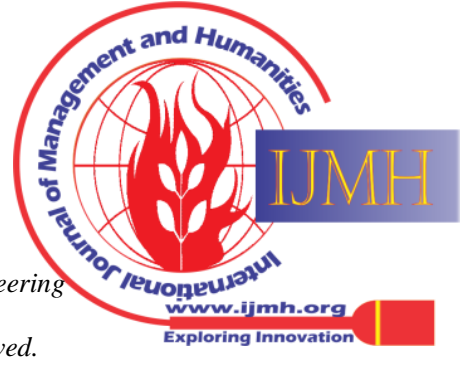




\section{Definition of Work Performance}

Mangkunegara (2017) says that performance or work performance is the result of work in quality and quantity achieved by an employee in carrying out his duties in accordance with the responsibilities assigned to him. According to Rahardjo et al. (2016), employee performance is the result of work or activities of an employee both in quality and quantity according to their responsibilities carried out within a certain period of time to increase the value of their company.

\section{E. Conceptual Framework}

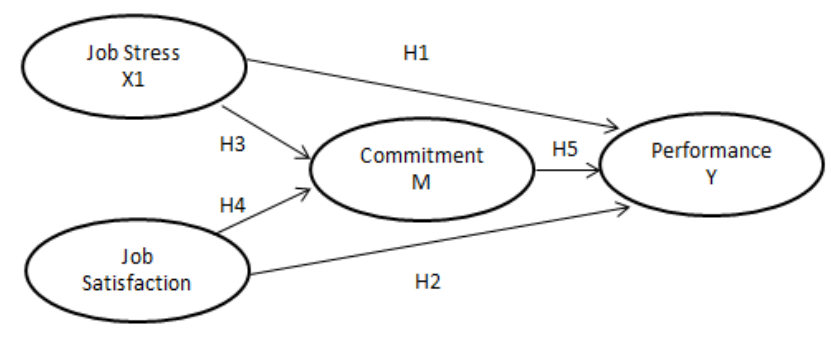

Figure 2.1 Conseptual Framework

Data Sources : Develoved for research

Work stress is a condition in which drivers online motorcycle taxi Grabbike experience uncomfortable and happy conditions with the work they do. This condition will have an influence on the work commitment of the drivers themselves. Commitment will be a mediating variable between job stress and the performance of drivers Grab.

Satisfaction as an independent variable is also closely related to work commitment and will affect the performance of Grabbike drivers. The better their satisfaction with the company, the higher the work commitment of Grabbike drivers. Work commitment is also closely related to the performance of Grabbike drivers . This study serves as a mediating variable between satisfaction and performance Grabbike drivers of the Palembang city.

\section{F. Research hypothesis}

H1: Job stress has a direct effect on employee performance

H2: Job satisfaction has a direct effect on employee performance

H3: Job stress has a direct effect on employee commitment

H4: Job satisfaction has a direct effect on organizational commitmenthas a direct

H5: Organizational commitment has a direct effect on employee performance

H6: Job stress has an indirect effect on performance through commitment as an intervening variable

H7: Job satisfaction has an indirect effect on performance through commitment as an intervening variable

\section{RESEARCH METHODS}

\section{A. Research Sites}

This research was conducted in Palembang city as the research location. Besides Palembang is a big city, Palembang is also one of the operational areas for Grabbike drivers.

\section{B. Population and Sample}

According to Sekaran (2013: 240) population refers to all groups of people, events or things that are interesting for research by researchers. Based on data collected from the official account of Facebook group "Sahabat Grabbike
Palembang " the amount of population obtained is 2576 drivers. The sample according to Sekaran (2013: 241) is part of the population, the

determination of the number of samples is based on the opinion of Hair et.al (2006) which provides recommendations for the Structural Equation Model (SEM) at least 100-150 respondents. Bryne (2001) states that the acceptable sample size for estimating SEM is at least 100 respondents. Determination of the sample also uses the Slovin technique (Sugiyono, 2011: 87). Based on several opinions of experts and using the Slovin technique in determining the number of samples in this study, it was decided that the sample size was 100 respondents.

\section{Types and Sources of Data}

The types of data processed in this study aredata primary. According to Sekaran (2013: 113)data primary refers to information obtained first-hand by researchers on variables of interest for specific research purposes.data Primary in this study were obtained through distributing questionnaires to respondents, namely Grabbike drivers. In addition, supporting data is also obtained through secondary data obtained through websites, media and books related to research.

\section{Data collection methods Data}

Collection is carried out by giving questionnaires to respondents who are sampled. According to Sekaran (2013: 147) a questionnaire is to formulate a set of written questions for respondents to get answers.

\section{E. Data Analysis Techniques}

Testing the research hypothesis was carried out using theapproach Structural Equation Model (SEM) using Partial Least Square (PLS). PLS is a component or variance based structural equation model (SEM ). According to Latan and Ghozali (2012) PLS is an alternative approach that shifts from abased SEM approach covariance -based to variant-. Covariance-based SEM generally tests causality / theory, while PLS is more of a predictive

\section{RESULT AND DISCUSSION}

\section{A. PT Grab Indonesia}

Grab was founded by Anthony Tan and Hooi Ling Tan who are Malaysian citizens, Grab is one of the most popular transportation services in the Southeast Asia region which now operates in several countries such as Malaysia, Indonesia, Vietnam, Thailand, Singapore and Philippines. Grab is here as an alternative driving route for drivers and passengers who prioritize speed, safety and certainty. Grab was present in Indonesia in June 2015 and was present in the city of Palembang in August 2017.

\section{B. Research Instruments Test Result}

\section{Validity Test}

Validity test were conducted to determine whether the indicators used reflect each of its constructs. The following is a table of validity test results :

Published By:

Blue Eyes Intelligence Engineering

\& Sciences Publication

(C) Copyright: All rights reserved.

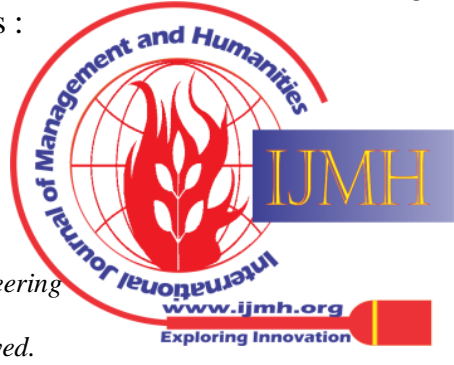


Table I :Results of Validity Test

\begin{tabular}{|c|c|c|c|c|}
\hline Indicator & $\begin{array}{c}\text { Job } \\
\text { Stress }\end{array}$ & $\begin{array}{c}\text { Job } \\
\text { Satisfaction }\end{array}$ & $\begin{array}{c}\text { Organizational } \\
\text { Commitment }\end{array}$ & Performance \\
\hline BK & $\mathbf{0 , 8 7 1}$ & $-0,772$ & $-0,818$ & $-0,807$ \\
\hline TK1 & $\mathbf{0 , 8 3 3}$ & $-0,806$ & $-0,787$ & $-0,781$ \\
\hline TK2 & $\mathbf{0 , 8 7 7}$ & $-0,833$ & $-0,837$ & $-0,829$ \\
\hline UB & $\mathbf{0 , 8 7 3}$ & $-0,818$ & $-0,813$ & 0,812 \\
\hline TAW & $\mathbf{0 , 8 7 5}$ & $-0,801$ & $-0,819$ & $-0,813$ \\
\hline BBO1 & $\mathbf{0 , 8 8 8}$ & $-0,850$ & $-0,816$ & $-0,833$ \\
\hline BBO2 & $\mathbf{0 , 8 9 1}$ & $-0,819$ & $-0,833$ & $-0,815$ \\
\hline PS1 & $-0,842$ & $\mathbf{0 , 8 7 8}$ & 0,827 & 0,839 \\
\hline PS2 & $-0,812$ & $\mathbf{0 , 8 8 2}$ & 0,814 & 0,837 \\
\hline SU & $-0,762$ & $\mathbf{0 , 8 1 7}$ & 0,805 & 0,790 \\
\hline OM1 & $-0,864$ & $\mathbf{0 , 8 7 2}$ & 0,834 & 0,836 \\
\hline KM & $-0,793$ & $\mathbf{0 , 8 6 4}$ & 0,780 & 0,801 \\
\hline KF1 & $-0,810$ & $\mathbf{0 , 8 8 9}$ & 0,841 & 0,819 \\
\hline KF2 & $-0,778$ & $\mathbf{0 , 8 3 6}$ & 0,711 & 0,793 \\
\hline RK1 & $-0,787$ & $\mathbf{0 , 8 2 3}$ & 0,773 & 0,809 \\
\hline RK2 & $-0,698$ & $\mathbf{0 , 7 9 7}$ & 0,726 & 0,775 \\
\hline KP & $-0,747$ & $\mathbf{0 , 8 2 5}$ & 0,758 & 0,775 \\
\hline KA1 & $-0,829$ & 0,828 & $\mathbf{0 , 8 6 3}$ & 0,828 \\
\hline KA2 & $-0,773$ & 0,771 & $\mathbf{0 , 8 2 9}$ & 0,807 \\
\hline KA3 & $-0,820$ & 0,810 & $\mathbf{0 , 8 8 4}$ & 0,811 \\
\hline KN & $-0,846$ & 0,826 & $\mathbf{0 , 8 8 1}$ & 0,818 \\
\hline KB & $-0,833$ & 0,824 & $\mathbf{0 , 9 0 5}$ & 0,806 \\
\hline KK1 & $-0,809$ & 0,785 & 0,813 & $\mathbf{0 , 8 1 5}$ \\
\hline KK2 & $-0,801$ & 0,820 & 0,806 & $\mathbf{0 , 8 3 6}$ \\
\hline KK3 & $-0,726$ & 0,794 & 0,739 & $\mathbf{0 , 8 0 5}$ \\
\hline KU1 & $-0,799$ & 0,815 & 0,777 & $\mathbf{0 , 8 5 5}$ \\
\hline KU2 & $-0,815$ & 0,809 & 0,799 & $\mathbf{0 , 8 3 2}$ \\
\hline KD1 & $-0,816$ & 0,837 & 0,823 & $\mathbf{0 , 8 9 1}$ \\
\hline KD2 & $-0,779$ & 0,774 & 0,763 & $\mathbf{0 , 8 6 5}$ \\
\hline KD3 & $-0,781$ & 0,822 & 0,792 & $\mathbf{0 , 8 6 9}$ \\
\hline
\end{tabular}

Data Sources : Processed from the Questionnaire, 2021

Testing is carried out to prove whether the indicators in a construct are able to reflect the construct itself. Indicators that reflect the construct itself will have a higher loading factor value than the loading factor value of other constructs. In addition, the cross loading value of the indicator in the construct must be> 0.7 in order to be declared valid (Jogiyanto \& Abdillah, 2014). Thus, the construct will predict each indicator in its block better than other block indicators.

Based on table I it can be seen that the reflective indicators of work stress constructs (BK, TK1, TK2, UB, TAW, BBO1, BBO2) have a loading factor value above 0.7 and have a value loading factor is higher in its own construct than in other constructs. As an illustration, the loading factor value of work stress on the BK indicator is 0.871 , higher than the constructs of job satisfaction (0.772), organizational commitment (0.818) and performance (0.807). This means that all indicators on job stress is declared valid

The test results in table I also prove that the indicators that reflect the job satisfaction construct also have a loading factor that is higher than the loading factor with other constructs. Likewise, the indicators that reflect organizational commitment and performance show that the loading factor value in the construct is higher than the loading factor with other constructs. Overall it can be concluded that the indicators that reflect the constructs of job stress, job satisfaction, organizational commitment and performance are declared valid.

\section{Realibility Test}

In addition to the validity test on each construct indicator, a reliability test was also carried out on each construct. The following is a table of reliability test results:
Tabel II : Hasil Uji Realibility

\begin{tabular}{|c|c|c|c|}
\hline Construct & $\begin{array}{c}\text { Cronbach' } \\
\text { Alpha }\end{array}$ & $\begin{array}{c}\text { Composite } \\
\text { Reliability }\end{array}$ & $\begin{array}{c}\text { Average Variances } \\
\text { Extracted (AVE) }\end{array}$ \\
\hline Job Stress & 0,948 & 0,957 & 0,762 \\
\hline Job Satisfaction & 0,956 & 0,962 & 0,717 \\
\hline Commitment & 0,922 & 0,941 & 0,762 \\
\hline Performance & 0,943 & 0,953 & 0,717 \\
\hline
\end{tabular}

Dipta Sources : Processed from the Questionnaire, 2021

Based on the results of table II we can see that the composite value for each construct must exceed 0.7 in order to meet the requirements of the SEM PLS rules of thumb (Hair, et. all, 2017: 102). Table II shows that the construct value for work stress is 0.957 , job satisfaction is 0.962 , for organizational commitment it is 0.941 and employee performance is 0.943 . This means that the composite reliability coefficient value for each construct is very good because it is $>0.7$.

Table II also shows the Cronbach 'Alpha value for each construct $>0.7$ which means it meets the requirements of the SEM PLS rules of thumb (Hair, et.all, 2017: 102). The Cronbach 'Alpha value for work stress is 0.948, for job satisfaction it is 0.956 , for organizational commitment it is 0.922 and employee performance is 0.943 . This means that for each Cronbach 'Alpha value meets the requirements because it is $>0.7$.

The Average Variances Extracted (AVE) value in table II shows that the value of each construct must be $>0.5$ (Ghozali \& Latan, 2015). The AVE value of the work stress construct was 0.762 , for job satisfaction it was 0.717 , for organizational commitment it was 0.762 and forperformance it employee was 0.717 . This means that the value of Average Variances Extracted (AVE) for all constructs is eligible because the AVE value $>0.5$.

\section{Structural Model Test}

Testing of the structural model in PLS is evaluated using R2 for the dependent variable and the path coefficient value for the independent variable which is then assessed for its significance based on the t-statistic value of each path. Following are the results of the R-Square model testing:

Tabel III : R Square and Adjusted R- Square

\begin{tabular}{|l|c|c|}
\hline & R-Square & $\begin{array}{c}\text { R-Square } \\
\text { Adjusted }\end{array}$ \\
\hline $\begin{array}{l}\text { Organization } \\
\text { Commitment }\end{array}$ & 0,906 & 0,904 \\
\hline Performance & 0,930 & 0,927 \\
\hline
\end{tabular}

Data Sources : Processed from the Questionnaire, 2021

Based on III results of the coefficient of determination on value R Square is 0.906 . This value can be interpreted that as much as $90.6 \%$ of the contribution of job stress and job satisfaction to organizational commitment, while the remaining $9.4 \%$ is influenced by other factors outside of these variables. The coefficient of determination on the $\mathrm{R}$ Square value for job stress and job satisfaction on employee

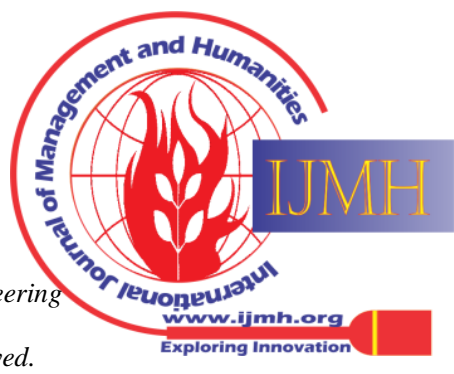


performance is 0.930 or $93 \%$ influenced by these variables and the remaining $7 \%$ is influenced by other variables. The following is a captured image of the structural test results:

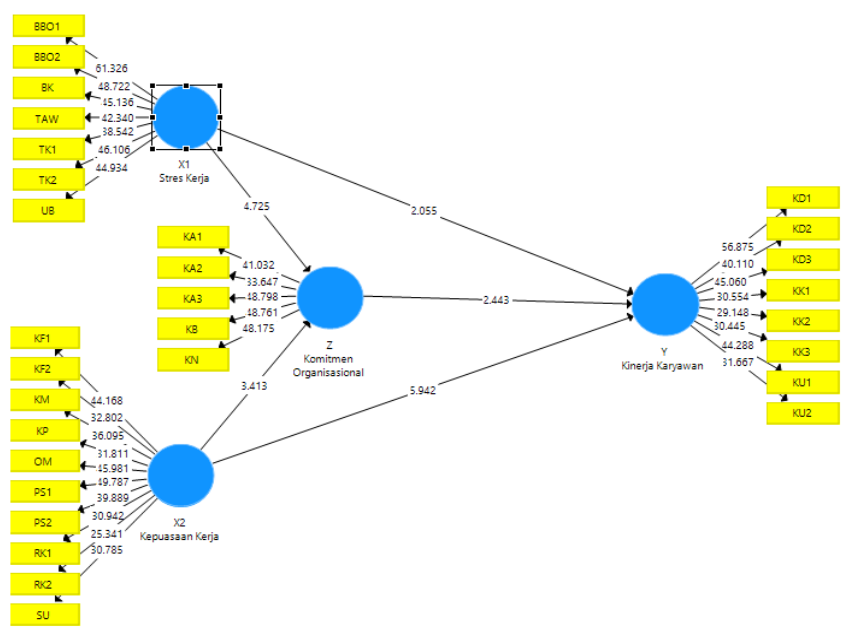

Figure 2.2 Output SEM-PLS

Data Saource: Processed from the Questionnaire, 2021

To assess the significance of the prediction model in testing the structural model, it can be seen from the t-statistic value between the independent variable and the dependent variable in the Path Coefficient table on the SmartPLS output below:

Table IV : Result of PLS Boothstrapping Path Coefficient

\begin{tabular}{|c|c|c|c|c|}
\hline & $\begin{array}{c}\text { Original } \\
\text { sample } \\
\text { estimate }\end{array}$ & $\begin{array}{c}\text { Mean of } \\
\text { subsamples }\end{array}$ & $\begin{array}{c}\text { Standart } \\
\text { Deviation }\end{array}$ & T-Statistic \\
\hline $\begin{array}{c}\text { workstres-> organizational } \\
\text { commitment }\end{array}$ & $-0,556$ & $-0,557$ & 0,118 & 4,725 \\
\hline workstres-> perfomance & $-0,226$ & $-0,231$ & 0,110 & 2,055 \\
\hline $\begin{array}{c}\text { job satisfaction> } \\
\text { organizational commitment }\end{array}$ & 0,411 & 0,410 & 0,120 & 3,413 \\
\hline $\begin{array}{c}\text { job satisfaction > } \\
\text { performance }\end{array}$ & 0,542 & 0,537 & 0,091 & 5,942 \\
\hline $\begin{array}{c}\text { organizational commitment - } \\
\text { > performance }\end{array}$ & 0,217 & 0,215 & 0,089 & 2,443 \\
\hline
\end{tabular}

Data Sources : Processed from the Questionnaire, 2021

Meanwhile, to see the indirect effect between dependent and independent variables is shown in the table below:

Table V : Result of PLS Boothstrapping Indirect Effect

\begin{tabular}{|c|c|c|c|c|}
\hline & $\begin{array}{c}\text { Original } \\
\text { sample } \\
\text { estimate }\end{array}$ & $\begin{array}{c}\text { Mean of } \\
\text { subsamples }\end{array}$ & $\begin{array}{c}\text { Standart } \\
\text { Deviation }\end{array}$ & $t$-Statistic \\
\hline $\begin{array}{c}\text { workstres }>\text { organizational } \\
\text { commitment }>\text { performance }\end{array}$ & $-0,121$ & $-0,121$ & 0,059 & 2,041 \\
\hline $\begin{array}{c}\text { job satisfaction }>\text { organizational } \\
\text { commitment- }>\text { performance }\end{array}$ & 0,089 & 0,087 & 0,043 & 2,082 \\
\hline
\end{tabular}

Data Sources : Processed from the Questionnaire, 2021

Based on Figure 2.2 and Table IV shows that the relationship Between work stress and organizational commitment is significant with a significance value below $5 \%$ as indicated by the t-statistic of 4.725 ( $>1.96)$. The original sample estimate value is negative, which is -0.556 which indicates that the direction of the relationship between work stress and organizational commitment is negative. Based on the results of the data processing, it can be concluded that the first hypothesis is accepted.

The results of table IV data processing show that the relationship between job satisfaction and organizational commitment is significant with a significance value below $5 \%$ as indicated by the t-statistic of $3,413(>1.96)$. The original sample estimate value is positive, namely 0.411 which indicates that the direction of the relationship between job satisfaction and organizational commitment is positive. Based on the results of table IV data processing,is the second hypothesis accepted.

The results of data processing in Table IV show that the relationship between job stress and employee performance is significant with a significance value below $5 \%$ as indicated by the t-statistic of 2.055 ( $>1.96)$. The original sample estimate value is negative, which is -0.556 which indicates that the direction of the relationship between work stress and employee performance is negative. Based on the results of the data processing, it can be concluded that the third hypothesis is accepted.

The results of data processing in Table IV show that the relationship between job satisfaction and employee performance is significant with a significance value below $5 \%$ as indicated by the t-statistic of 5,942 (> 1.96). The original sample estimate value is positive, which is 0.542 which indicates that the direction of the relationship between job satisfaction and employee performance is positive. Based on the results of the data processing, it can be concluded that the fourth hypothesis is accepted.

Likewise, table IV shows that the relationship between organizational commitment and employee performance is significant with a significance value below $5 \%$ as indicated by the t-statistic of 2.443 ( $>1.96)$. The original sample estimate value is positive, namely 0.217 which indicates that the direction of the relationship between organizational commitment and employee performance is positive. Based on the results of the data processing, it can be concluded that the fifth hypothesis is accepted.

Based on Table V, it shows that the indirect relationship between job stress and employee performance through organizational commitment is significant with a significance value below $5 \%$ which is shown by the t-statistic of 2.041 (> 1.96). The original sample estimate value is negative, which is equal to -0.121 which indicates that the direction of the indirect relationship between work stress and employee performance through organizational commitment is negative. This explains that the role of organizational commitment as a mediating variable is partial mediation (not full mediation). Based on the results of the data processing, it can be concluded that the sixth hypothesis is accepted.

Table $\mathrm{V}$ also shows that the indirect relationship between job satisfaction and employee performance through organizational commitment is significant with a significance value below $5 \%$ indicated by the t-statistic of 2.082 (> 1.96).

The original sample estimate value is positive, namely 0.089 which indicates that the direction of the indirect relationship between job satisfaction and employee performance through organizational commitment is positive. This explains that the role of organizational commitment as a mediating variable is partial mediation (not full mediation). Based on the results of the data processing, it can be concluded that the seventh hypothesis is accepted.

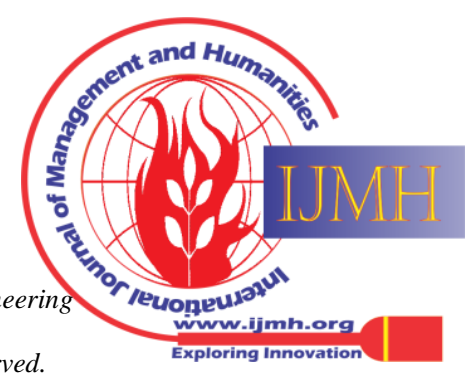




\section{DISCUSSION}

\section{The Effect of Job Stress and Employee Performance}

Based on the statistical calculations that have been done, it is known that hypothesis 1 is accepted, which means that job stress has a negative and significant effect on employee performance. The relationship between job stress and employee performance will form an inverted U-relationship pattern as described by (Robbins \& Judge, 2017). This relationship suggests that the underlying logic behind $U$ is that it is that low to medium stress levels stimulate the body and increase its ability to react.

Research by Handaru et al. (2017) show that job stress has a negative and significant effect on employee performance. This means that stress that is not managed properly will have a negative impact on employee performance. Where the high level of stress will result in decreased employee performance. This happens because in a state of high stress and pressure, employees find it difficult to develop themselves and their to prevent their Grabbike drivers from working stressful conditions. This needs to be done because the role of Grabbike drivers in company performance is very important, where Grabbike drivers directly provide services to consumers. The better the service that Grabbike drivers provide to consumers, the better it will be for the company's image. This means that when the company is able to reduce the level of work stress, it will increase the company's performance.

\section{The Effect of Job Satisfaction and Employee Performance}

Based on the statistical calculations that have been done, it is known that hypothesis 2 is accepted, which means that job satisfaction has a positive and significant effect on employee performance. Based on the original sample estimate value of 0.542 which indicates that the direction of the relationship between job satisfaction and employee performance is positive. This relationship shows that the higher a person's job satisfaction level at work, the the higher the performance they will do (Safrizal, 2013).

This study is also in line with research conducted by Noor et al. (2016) and Wirya et al. (2019) which states that job satisfaction has a significant and positive influence on employee performance. Employees get job satisfaction obtained from the leadership and the organization, so that employee job satisfaction has a positive and significant influence in improving employee performance.

One of the efforts made by Grab to increase job satisfaction for Grabbike drivers is by providing incentives if job targets are met. In addition, Grab is also active in providing free shopping vouchers at minimarkets and in the form of other Grab benefits to maintain Grabbike drivers' job satisfaction. Good job satisfaction will encourage Grabbike drivers to work optimally and provide the best service to consumers. Good service to consumers will ultimately increase performance.

\section{The Effect of Job Stress and Organizational Commitment} job stress has a negative and significant effect on organizational commitment. This shows that high work stress will reduce organizational commitment. In line with the creativity.

Grab as a company that houses Grabbike drivers must try

Based on the results of testing hypothesis 3 , it shows that

research of Noor et al., (2016), Ariawan \& Sriathi (2017) and Ekienabor (2019), it shows that job stress has a negative and significant effect on organizational commitment. This means that if the company can reduce and manage the level of stress experienced by employees, it will increase the organizational commitment of employees to the company.

One of the efforts made by Grab to prevent Grabbike drivers from work stress is to provide enthusiasm and motivation through online print meetings. Apart from being a means of encouraging and motivating to avoid work stress, this activity is also carried out to accommodate suggestions and input from Grabbike drivers. Stress-free Grabbike drivers will do a good job and will have a high organizational commitment to their company.

\section{The Effect of Job Satisfaction and Organizational Commitment}

Based on the statistical calculations that have been done, it is known that hypothesis 4 is accepted, which means that job satisfaction has a positive and significant effect on organizational commitment. The effect of job satisfaction on organizational commitment is the most dominant indicator where the t-statistic value is 5,942. Job satisfaction of employees varies from one another, this happens because the needs of employees are different. Employee job satisfaction will encourage productivity at work and create a sense of belonging to the company. The higher the employee's job satisfaction, the higher the organizational commitment (Arianti, 2018). Employees who have feelings of excitement about work will have a feeling of ownership of the company.

This study is also in line with the research of Malik et al. (2010) and Loan (2020) which state that job satisfaction has a significant and positive influence on organizational commitment. This means that organizational commitment will be created if employees feel satisfaction with the work they do. Satisfied employees will be more able to commit to their company because employees feel happy being there.

Companies must be able to create job satisfaction for employees in order to improve maximum service quality (Munhurrun et al., 2010). Grabbike drivers who have good job satisfaction will provide the best service to consumers. Consumers who are satisfied with the maximum service from Grabbike drivers will improve the company's image. Job satisfaction will also have an impact on organizational commitment, where the higher the job satisfaction, the higher the organizational commitment.

\section{The Effect of Organizational Commitment and Employee Performance}

Based on the statistical calculations that have been done, it is known that hypothesis 5 is accepted, which means that organizational commitment has a positive and significant effect on employee performance. Based on the original sample estimate value of 0.217 which indicates that the direction of the relationship between organizational commitment and employee performance is positive. Employees who have good organizational commitment will be of value to the organization, where in turn the employees will provide good performance for the company. 
The higher the organizational commitment, the higher the employee's performance (Supriyanto, 2013).

This research is also in line with previous research conducted by Suyanto \& Hendri (2019) and Loan (2020) which states that organizational commitment has a positive and significant effect on employee performance. This means that the better a person's commitment to the company, the better the performance they produce for the company. This shows that employees who have high organizational commitment will help the company to have high performance as well.

Grabbike drivers who have the desire to be tied to the company will maximize their every ability while carrying out their duties and responsibilities. Grabbike drivers who devote all their abilities to work will help improve company performance. The higher the organizational commitment they have, the higher the performance they have.

Organizational commitment has a very important role in an organization, because employees who have a high commitment will do their job as well as possible and in the end have a good impact on the employee's performance. As an online print transportation company, Grab strives to continue to increase the commitment of Grabbike drivers by continuing to make improvements to the performance of the application and service complaints when work problems occur in the field. In addition, Grab also always receives input and suggestions from Grabbike drivers to continue improving services to all drivers. Grabbike drivers who have a good commitment will provide maximum service to customers and will ultimately help improve their performance

\section{Indirect Effect of Job Stress and Employee Performance through Organizational}

Commitment Based on the statistical results in table $\mathrm{V}$ it shows that the sixth hypothesis which means organizational commitment is successful in mediating between job stress and employee performance. Although organizational commitment is successful as a mediating variable, commitment does not fully mediate (full mediation) between job stress and employee performance. This happens because basically work stress and employee performance already have a significant relationship. So, organizational commitment only acts as a partial mediation variable (partial mediation). Partial mediation states that the mediating variable accounts for some, but not all, of the relationship between the independent variable and the dependent variable. Partial mediation implies that there is not only a significant relationship between the mediator and the dependent variable, but also some direct relationship between the independent and dependent variables. According to Suliyanto (2011) partial mediation, directly or indirectly, the independent variable affects the dependent variable.

The better organizational commitment, it will encourage employees to have good performance as well. Heavy workload and pressure will cause Grabbike drivers to experience work stress. If work stress is not managed properly it will impact on organizational commitment and in the end will have an impact on the performance of the company. Grabbike drivers who are able to manage work stress well will work with high motivation and enthusiasm. In addition, Grabbike drivers who are able to reduce stress levels at work tend to have good organizational commitment. Good organizational commitment will improve the performance of Grabbike drivers. In addition to job stress, the relationship between job satisfaction and employee performance is mediated by organizational commitment.

\section{Indirect Effect of Job Satisfaction and Employee Performance through Organizational}

Commitment Based on the statistical results in table $\mathrm{V}$ it shows that the seventh hypothesis is accepted, which means that organizational commitment is successful in mediating between job stress and employee performance. The direction of the indirect relationship can be seen from the original sample estimate value of 0.089 . This means that the relationship is positive. Furthermore, job satisfaction for employees in the company will encourage them to have a good commitment to the company. Then a good commitment will encourage employees to have good performance.

In addition, the role of organizational commitment as a mediating variable between job satisfaction and employee performance variables is only partial mediation. This happens because both directly and indirectly the job satisfaction variable has an influence on employee performance variables (Suliyanto, 2011). This also shows that the existence of a mediating variable does indeed contribute to some and not fully the relationship between job satisfaction and employee performance variables. This means that with or without the mediating variable, the independent variable and the dependent variable have a significant effect.

This study is in line with previous research conducted by Kristianto et al. (2010) which proved that there was an indirect influence between job stress on employee performance through organizational commitment. This proves that job satisfaction, either directly or indirectly, through organizational commitment as a mediating variable, has a significant and positive effect on employee performance.

Grabbike drivers who have good job satisfaction will do the job happily. Satisfied Grabbike drivers will work comfortably and are loyal to their work. Job satisfaction will also have an impact on the emotional condition of Grabbike drivers, where job satisfaction will drive good work productivity. The higher the job satisfaction of the Grabbike drivers will have an impact on organizational commitment, which in the end also has a positive impact on employee performance.

\section{CONCLUSION}

Based on the results of the research conducted, the following conclusions can be drawn:

1. There is a significant direct effect between job stress and job satisfaction on organizational commitment.

2. There is a significant direct effect between job stress and job satisfaction on employee performance.

3. There is a significant direct influence between organizational commitment on employee performance.

4. There is an indirect and significant effect between job stress and job satisfaction on employee performance through organizational commitment as a mediating variable.

\section{Published By:}

Blue Eyes Intelligence Engineering \& Sciences Publication

(C) Copyright: All rights reserved. 


\section{REFERENCES}

1. Abdillah, W., \& Jogiyanto. (2014). Konsep \& Aplikasi PLS (Partia Least Square) untuk Penelitian Empiris. Yogyakarta: BPFE.

2. Arianti, M. (2018). Pengaruh Stres Kerja dan Kepuasan Kerja Terhadap Kinerja Karyawan Dengan Komitmen Organisasi Sebagai Variabel Intervening (Studi Kasus Pada Kantor Wilayah Kementrian Agama Provinsi Riau). Universitas Islam Indonesia. https://doi.org/https://dspace.uii.ac.id/

3. Ariawan, P. A. Y., \& Sriathi, A. A. A. (2017). Pengaruh Stres Kerja Dan Kepuasan Kerja Terhadap Komitmen Organisasi Karyawan Pbf. Pt. Banyumas Denpasar. E-Jurnal Manajemen Universitas Udayana, Vol. 7(No 2), 964. https://doi.org/10.24843/ejmunud.2018.v7.i02.p15

4. Byrne, B. M. (2001). Structural Equation Modelling with Amos, and Programming. London: Lawrance Erlbaum Associates Publishers.

5. Ekienabor, E. (2019). Impact of Job Stress on Employee's Productivity and Commitment. International Journal for Research in Business, Management and Accounting, Volume 2(5), 124-133. https://www.researchgate.net/publication/334559841

6. Ghozali, Imam \& Latan, H. (2015). Partial Least Square Konsep Teknik dan Aplikasi Menggunakan Program SmartPLS 3.0 (2nd Edition). Badan Penerbit Universitas Diponegoro.

7. Hair, et al. (2006). Multivariate Data Analysis. Pearson International Edition Edition 6. New Jersey.

8. Hair, et al. (2017). A Primer on Partial Least Squares Structural Modeling Equation (PLS-SEM). Los Angles : SAGE

9. Handaru, A. W., Syafiah, N. H., \& Parimita, W. (2017), the Influence of Work Environment and Work Stress on Employee Performance At Pt "S" Jakarta. JRMSI - Jurnal Riset Manajemen Sains Indonesia, 8(2), 298. https://doi.org/10.21009/jrmsi.008.2.07

10. Hasibuan, M. S. . (2016). Manajemen Sumber DayaManusia Edisi Revisi. PT.Bumi Aksara.

11. Kaswan. (2017). Pisikologi Industri dan Organisasi. Alfabeta; Bandung.

12. Kristianto, D., Suharmono, \& Ratnawati, I. (2010). Pengaruh Kepuasan Kerja Terhadap Kinerja Karyawan Dengan Komitmen Organisasional Sebagai Variabel Intervening (Studi pada RSUD Tugurejo Semarang). 1-11.

13. Lailiyah, U. W., \& Wahyuningsih, T. harsini. (2019). Analisis Faktor-Faktor Yang Mempengaruhi Kinerja Driver Grab-Bike Kabupaten Banjarnegara. Jurnal Manajemen Dan Bisnis Media Ekonomi, 19(1), 190-201.

14. Lawler, E. (2015). Global Trends in Human Resource Management: A Twenty-Year Analysis. Stanford Business Books.

15. Loan, L. T. M. (2020). The influence of organizational commitment on employees' job performance: The mediating role of job satisfaction. Management Science Letters, 10(14), 3307-3312. https://doi.org/10.5267/j.msl..6.007

16. Malik, M. E., Nawab, S., Naeem, B., \& Danish, R. Q. (2010). Job Satisfaction and Organizational Commitment of University Teachers in Public Sector of Pakistan. International Journal of Business and Management, 5(6). https://doi.org/10.5539/ijbm.v5n6p17

17. Mangkunegara, A. P. (2017). Evaluasi Kinerja SDM, Cetakan Kedelapan. PT. Refika Aditama.

18. Munhurrun, P. ., Naido, P., \& Bhiwajee, S. (2010). . 2010. Measuring service quality: perceptions of employees. Journal of business research, Vol 4, No.1, pp 47-58. Journal of Business Research Pp 47-58., Vol 4(1).

19. Noor, N. N., Rahardjo, K., \& Ruhana, I. (2014). Pengaruh Stres Kerja Dan Kepuasan Kerja Terhadap Kinerja Karyawan (Studi Pada Karyawan PT JasaRaharja (Persero) CabangJawaTimur di Surabaya) Nasyadizi. Jurnal Administrasi Bisnis, 1(2), 1-20.

20. Olaimat, D. (2017). The Moderating Effect of Organizational Support on the Relationship between Job Stress and Employee Performance in. t, 9(14). European Journal of Business and Managemen, Vol 9(14).

21. Rahardjo, Daryanto. 2016. Teori Komunikasi. Yogyakarta: Gava Media.

22. Retnawati, H. (2016). Analisis Kuantitatif Instrumen Penelitian. Yogyakarta: Parama Publishing.

23. Rivai, V. (2013). Manajemen Sumber Daya Manusia Untuk Perusahaan Dari Teori Ke Praktik. Salemba Empat, Jakarta, 2009.

24. Robbins, P. Stephen \& Judge, T. A. (2017). Organizational Behaviour, Edisi 13, Jilid 1. Salemba Empat, Jakarta.

25. Safrizal, H. B. A. (2013). Bisma jurnal bisnis dan manajemen. Jurnal Bisnis Dan Manajemen Volume 6 No. 1 Agustus, 13(1), 43-51.

26. Sekaran, U. (2013). Research Methods for Business. Jakarta: Salemba Empat.

27. Sugiyono. (2011). Metode Penelitian Bisnis. Bandung. CV. Alfabeta.

28. Suharto, Suyanto, \& Hendri, N. (2019). The impact of organizational commitment on job performance. International Journal of Economics and Business Administration, 7(2), 189-206. https://doi.org/10.35808/ijeba/227

29. Suliyanto. (2011). Ekonometrika Terapan Teori dan Aplikasi dengan SPSS. Yogyakarta: CV. Andi.

30. Supriyanto, A. S. (2013). Role of Procedural Justice, Organizationa Commitment and Job Satisfaction on job Performance: The Mediating Effects of Organizational Citizenship Behavior. International Journal of Business and Management, 8(15), 57-67. https://doi.org/10.5539/ijbm.v8n15p57

31. Triatna, C. (2015). Perilaku Organisasi. Cetakan Pertama. Bandung: PT Rosdakarya.

32. Wirya, K. ., Andiani, N. ., \& Telagawathi, N. L. W. S. (2019) Pengaruh Stres Kerja Dan Kepuasan Kerja Terhadap Kinerja Pegawai. Jurnal Manajemen Dan Bisnis, Volume 2(1), 50-60. https://doi.org/P-ISSN: 2685-5526

\section{AUTHORS PROFILE}

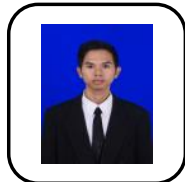

Ismail Marzuki, S.E Student Magister Management , Economic Faculty of Sriwijaya University, Palembang, Indonesia Email: ismailmarzuki280694@gmail.com

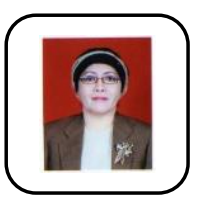

Dr. Hj. Agustina Hanafi, M.B.A Lecturer of Magister Management, Economic Faculty, Sriwijaya University, Palembang Indonesia

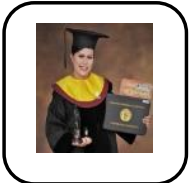

Dr. Yuliani, S.E., M.M Lecturer of Magister Management, Economic Faculty, Sriwijaya University, Palembang Indonesia
Published By:

Blue Eyes Intelligence Engineering \& Sciences Publication (C) Copyright: All rights reserved. 